DOI https://doi.org/10.30929/2307-9770.2020.08.04.01

UDC 615:61:378:37.091.313; 34.05

\title{
Realization of the human right to education in quarantine conditions: Ukrainian realities
}

\author{
Kalyniuk N. M.* \\ I. Horbachevsky Ternopil National Medical University, Ternopil, Ukraine
}

Received: 01.10 .2020

Accepted: 20.12 .2020

\begin{abstract}
It is substantiated that one of the effective ways to protect human and civil rights in Ukraine is a synergistic combination of mechanisms of state power to protect these rights and freedoms. The article is devoted to the problem of realization by a person of the constitutional right to education in the conditions of quarantine restrictions. In general, the current legislation on protection of the population from infectious diseases is not properly applied in Ukraine. It is emphasized that the availability of education as a constitutional guarantee of the realization of the right to education on the principles of equality defined by Art. 24 of the Constitution of Ukraine is that no one can be deprived of the right to education, and the state must create opportunities for the exercise of this right. The problematic aspects of the implementation of the constitutional right to education in the conditions of quarantine established in the state and the approved anti-epidemic measures for the spread of acute respiratory disease COVID-19 caused by the coronavirus SARS-CoV-2 are considered. The shortcomings of the current legislation regulating the implementation of the individual and the right to education in the context of the COVID-19 pandemic are highlighted. It is established that the legal grounds for the introduction of an emergency situation in Ukraine are the Law of Ukraine "On Ensuring the Sanitary and Epidemic Welfare of the Population" and the Law of Ukraine "On Protection of the Population from Infectious Diseases". However, neither the Law of Ukraine "On Ensuring the Sanitary and Epidemic Welfare of the Population" nor the Law of Ukraine "On Protection of the Population from Infectious Diseases" can provide the Cabinet of Ministers of Ukraine with restrictions on constitutional rights and freedoms under Article 64 of the Constitution. restrictions only in case of martial law or state of emergency. The mechanisms of realization by a person of the constitutional right to education in the conditions of established quarantine restrictions are clarified. Distance learning has been studied as the only possible alternative to the usual mode of attending secondary schools. It is proved that currently in schools there is no opportunity, time, funds for the organization of system and technical support of distance learning, therefore, the only possible form of education is to visit schools in the usual way. In addition, we draw your attention to the fact that before the beginning of the school year, education authorities at both regional and regional levels, local governments, which under current law are required to comply with the orders of the executive body implementing policy in the field of protection health in the context of preventing the spread of infectious diseases and the application of anti-epidemic measures, checking the readiness of educational institutions to work in quarantine realities. Schools are sufficiently provided with individual and collective protection. This allows them to operate and provide educational services to students.
\end{abstract}

Keywords: human rights, right to education, COVID-19, distance learning, quality of education, students

\section{Реалізація особою права на освіту в умовах карантину: українські реалії}

\section{Калинюк Н. М.}

Тернопільський національний медичний університет імені І. Я. Горбачевського, Тернопіль, Україна

\begin{abstract}
Анотація. Обгрунтовано, що одним із ефективних способів захисту прав людини і громадянина в Україні $\epsilon$ синергійне поєднання органами державної влади механізмів захисту цих прав і свобод. Стаття присвячена проблемі реалізації особою конституційного права на освіту в умовах карантинних обмежень. Узагальнено, що чинне законодавство з питань забезпечення захисту населення від інфеекційних хвороб не застосовується в Україні належним чином. Наголошено, що доступність освіти, як конституційна гарантія реалізації права на освіту на принципах рівності, визначених ст. 24 Конституції України полягає в тому, що нікому не може бути відмовлено у праві на освіту, і держава має створити можливості для реалізації цього права. Розглянуто
\end{abstract}

Corresponding Author: Kalyniuk Natalia Mykolayvna. Tel. +380976539021 .E-mail: kalunyknm@tdmu.edu.ua I. Horbachevsky Ternopil National Medical University, srt. M. Voli, 1, Ternopil, Ukraine.

Відповідальний автор: Калинюк Наталя Миколаївна. Тел. +380976539021 . E-mail: kalunyknm@tdmu.edu.ua Тернопільського національного медичного університету імені І.Я. Горбачевського, Майдан Волі, 1, м. Тернопіль, Україна, 46001. 
проблемні моменти реалізації особою конституційного права на освіту в умовах встановленого в державі карантину та затверджених протиепідемічних заходів щодо поширення гострої респіраторної хвороби COVID19, спричиненої коронавірусом SARS-CoV-2. Виокремлено недоліки чинного законодавства, що регулюють питання реалізації особою іі права на освіту в умовах пандемії COVID-19. Встановлено, що правовими підставами введення надзвичайної ситуації в Україні є Закон України "Про забезпечення санітарного та епідемічного благополуччя населення" та Закон України "Про захист населення від інфеекційних хвороб". Однак, ні Закон України "Про забезпечення санітарного та епідемічного благополуччя населення", ні Закон України "Про захист населення від інфекційних хвороб" не можуть наділяти Кабінет Міністрів України повноваженнями обмежувати конституційні права та свободи громадян в силу статті 64 Конституції України, яка встановлює можливість таких обмежень лише у випадку запровадження воєнного чи надзвичайного стану. 3'ясовано механізми реалізації особою конституційного права на освіту в умовах встановлених карантинних обмежень. Досліджено дистанційну форму навчання як єдину ймовірну альтернативу звичайного режиму відвідування загальноосвітніх закладів освіти. Доведено, що станом на даний час у школах відсутня можливість, час, кошти для організації системотехнічного забезпечення дистанційного навчання, відтак, єдино можливою формою здійснення навчання $€$ відвідування шкіл у звичайному режимі. Поряд з цим, звертаємо увагу на те, що до початку навчального року органами управління освіти як обласних так i регіональних рівнів, органами місцевого самоврядування, на яких чинним законодавством покладено зобов'язання з питань реалізації розпоряджень органу виконавчої влади, що здійснює політику у сфрері охорони здоров'я в контексті запобігання поширенню інфекційних хвороб та застосування протиепідемічних заходів, перевірку готовності закладів освіти до роботи у карантинних реаліях. Школи у достатніх обсягах забезпечені засобами індивідуального та колективного захисту. Це дає можливість їм закладам здійснювати діяльність та надавати освітні послуги здобувачам освіти.

Ключові слова: права людини, право на освіту, COVID-19, дистанційна форма навчання, якість освіти, здобувачі освіти

\title{
Реализация человеком права на образование в условиях карантина: украинские реалии
}

\author{
Калинюк Н. М. \\ Тернопольский национальный медицинский университет имени И. Я. Горбачевского, Тернополь, Украина
}

\begin{abstract}
Аннотация. Обосновано, что одним из эфффективных способов защиты прав человека и гражданина в Украине синергийного сочетание органами государственной власти механизмов защиты этих прав и свобод. Статья посвящена проблеме реализации лицом конституционного права на образование в условиях карантина. Обзор, что действующее законодательство по вопросам обеспечения защиты населения от инфрекционных болезней не применяется в Украине должным образом. Отмечено, что доступность образования, как конституционная гарантия реализации права на образование на принципах равенства, определенных ст. 24 Конституции Украины заключается в том, что никому не может быть отказано в праве на образование, и государство должно создать возможности для реализации этого права. Рассмотрены проблемные моменты реализации лицом конституционного права на образование в условиях установленного в государстве карантина и утвержденных противоэпидемических мероприятий по распространению острой респираторной болезни COVID-19, вызванной коронавируса SARS-CoV-2. Выделены недостатки действующего законодательства, регулирующие вопросы реализации лицом ии права на образование в условиях пандемии COVID-19. Установлено, что правовыми основаниями введения чрезвычайной ситуации в Украине является Закон Украины "Об обеспечении санитарного и эпидемического благополучия населения" и Закон Украины "О защите населения от инфекционных болезней". Однако, ни Закон Украины "Об обеспечении санитарного и эпидемического благополучия населения", ни Закон Украины "О защите населения от инфекционных болезней" не могут наделять Кабинет Министров Украины полномочиями ограничивать конституционные права и свободы граждан в силу статьи 64 Конституции Украины, которая устанавливает возможность таких ограничений только в случае введения военного или чрезвычайного положения. Выяснены механизмы реализации лицом конституционного права на образование в условиях установленных карантинных ограничений. Исследована дистанционную форму обучения как единую вероятную альтернативу обычному режиму посещения общеобразовательных учебных заведений. Доказано, что на настоящее время в школах отсутствует возможность, время, средства для организации системотехнического обеспечения дистанционного обучения, поэтому, единственно возможной формой осуществления обучения является посещение школ в обычном режиме. Наряду с этим, обращаем внимание на то, что к началу учебного года органами управления образования как областных так и региональных уровней, органами местного самоуправления, на которых действующим законодательством возложена обязанность по реализации предписаний органа исполнительной власти, осуществляющего политику в сфере охраны здоровья в контексте предотвращения распространения инфекционных болезней и применения
\end{abstract}


противоэпидемических мероприятий, проверку готовности учебных заведений к работе в карантинных реалиях. Школы в достаточных объемах обеспечены средствами индивидуальной и коллективной защиты. Это дает возможность им учреждениям осуществлять деятельность и предоставлять услуги соискателям образования.

Ключевые слова: права человека, право на образование, COVID-19, дистанционная форма обучения, качество образования, соискатели образования

\section{Bcmyn}

Українське суспільство, як і людство в цілому, перебуває під впливом потужних глобалізаційних Українське суспільство, як і людство в цілому, перебуває під впливом потужних глобалізаційних процесів, швидких змін умов життя, посилення конкурентних засад та утвердження дослідницькоінноваційного типу розвитку, переосмислення ціннісних орієнтирів і стратегій людського буття. Однією 3 основних передумов цих явищ і процесів є безкордонне та не лімітоване в часі й просторі поширення гострої респіраторної хвороби COVID-19, спричиненої коронавірусом SARS-CoV-2». Нові виклики вимагають адекватної модернізації освітньої системи як провідного чинника соціально-культурного відтворення, успішної життєдіяльності людини, її подальшого вдосконалення.

Проблематика реалізації прав людини в умовах пандемії $€$ однією з найактуальніших питань сьогодення і була предметом дослідження таких науковців різних галузей знань як В. Азагхуах-Ель Фарді [5, с. 536], М. Амстронг [6, с. 230], Р. Бач [7, с. 194 ], М. Барба [8, с. 315], Дж. Баєр [9, с. 11], Дж. Блеквел [10, с. 8], 3. Ванг [18, с. 738], Дж. Віллар [17, с. 717], Ф. Джагуга [13, с. 68], М. Дубе [12, с. 22], Т. Кадобний [14, с. 944], Н. Калинюк [1, с. 46; 2, с. 138; 14, с. 939], Дж. Лодж [11, с. 201], О. Лотоцька [14, с. 943], Т. Маркус [15, с. 60], Р. Меїх-Черечеда [16, с. 457], І. Мельничук [4], І. Рогальський [2, с. 134], Т. Федірчик [4], Т. Ху [19, с. 115] та ін. Резонансність та різносторонність цих досліджень вказує на актуальність обраної тематики щодо дослідження механізмів реалізації особою права на освіту в умовах карантину, здійснивши аналіз українського законодавства. Адже українська держава нині перебуває на переломному етапі щодо забезпечення гарантій громадянам, іноземцям та особам без громадянства основних прав і свобод людини і громадянина, зокрема, це стосується права на освіту та права на охорону здоров'я. Протиставляти один з одним ці людиноцентриські права не є доцільним.

Мета роботи. З'ясувати можливості синергійного поєднання гарантованих державою прав і свобод людини та громадянина щодо забезпечення особі реалізації її права на освіту та, відповідно, захисту населення від поширення інфекційних хвороб в умовах пандемії.

\section{II Матеріали і методи дослідження}

Для реалізації поставленої мети застосовано такий комплекс методів: теоретичного аналізу, порівняння, обґрунтування, узагальнення, систематизації теоретичного та практичного матеріалу, вивчення основних міжнародних та національних нормативно-правових актів у контексті характеристики клятви лікаря під час підготовки майбутніх фахівців медичної галузі на засадах міждисциплінарної інтеграції; формулювання і систематизації висновків.

\section{III Результати}

Відповідно до постанови Кабінету Міністрів України від 22 липня 2020 р. за № 641 «Про встановлення карантину та запровадження посилених протиепідемічних заходів на території із значним поширенням гострої респіраторної хвороби COVID-19, спричиненої коронавірусом SARS-CoV-2», установлено, що з метою запобігання поширенню на території України гострої респіраторної хвороби COVID-19, спричиненої коронавірусом SARS-CoV-2 (далі - COVID-19), з 1 серпня до 31 жовтня 2020 р. на території Автономної Республіки Крим, Вінницької, Волинської, Дніпропетровської, Донецької, Житомирської, Закарпатської, Запорізької, Івано-Франківської, Кіровоградської, Київської, Луганської, Львівської, Миколаївської, Одеської, Полтавської, Рівненської, Сумської, Тернопільської, Харківської, Херсонської, Хмельницької, Черкаської, Чернівецької, Чернігівської областей, м. Києва, м. Севастополя (далі - регіони) карантин, продовживши на всій території України дію карантину, встановленого постановами Кабінету Міністрів України від 11 березня 2020 р. № 211 «Про запобігання поширенню на території України гострої респіраторної хвороби COVID-19, спричиненої коронавірусом SARS-CoV-2» та 
від 20 травня 2020 р. № 393 «Про встановлення карантину з метою запобігання поширенню на території України гострої респіраторної хвороби COVID-19, спричиненої коронавірусом SARS-CoV-2» (далі Постанова).

Відповідно до п.2 вищевказаної Постанови, залежно від епідемічної ситуації в регіоні або районі чи місті обласного значення (далі - окремі адміністративно-територіальні одиниці регіону) встановлюється «зелений», «жовтий», «помаранчевий» або «червоний» рівень епідемічної небезпеки поширення COVID-19 (далі - рівень епідемічної небезпеки).

Згідно із п.3 Постанови, рівень епідемічної небезпеки встановлюється за результатом оцінки епідемічних показників та визначається рішенням Державної комісії з питань техногенно-екологічної безпеки та надзвичайних ситуацій, яке розміщується на офріційному інформаційному порталі Кабінету Міністрів України (за посиланням http://covid19.gov.ua).

Рішенням Державної комісії з питань техногенно-екологічної безпеки та надзвичайних ситуацій від 03.09.2020 року (протокол №28 від 03.09.2020р.) встановлено з 00 год. 00 хв. 7 вересня 2020 року «червоний» рівень епідемічної небезпеки поширення COVID-19 в Тернопільській області - в містах Тернопілі, Бережанах, Чорткові та у Бережанському, Бучацькому, Гусятинському, Монастириському, Теребовлянському, Тернопільському та Чортківському районах.

Відповідно до п.15 Постанови, на території регіону (адміністративно-територіальної одиниці), на якій установлено «червоний» рівень епідемічної небезпеки, додатково до протиепідемічних обмежень, передбачених для «зеленого», «жовтого» та «помаранчевого» рівня епідемічної небезпеки, забороняються:

1) регулярні та нерегулярні перевезення пасажирів автомобільним, залізничним транспортом, міським електротранспортом, метрополітеном у міському сполученні, крім перевезення:

легковими автомобілями, кількість пасажирів, включаючи водія, в яких не більше п'яти осіб без урахування осіб віком до 14 років;

службовими та/або орендованими автомобільними транспортними засобами підприємств, закладів та установ за умови забезпечення водіїв та пасажирів під час таких перевезень засобами індивідуального захисту в межах кількості місць для сидіння і виключно за маршрутами руху, про які поінформовано не менше ніж за два дні органи Національної поліції;

1-1) посадка пасажирів у транспорт приміського, міжміського, внутрішньообласного та міжобласного сполучення;

2) відвідування закладів освіти здобувачами освіти;

3) приймання відвідувачів суб'єктами господарювання, які провадять діяльність у ссрерах культури, кінотеатрів, закладів громадського харчування (ресторанів, кафе тощо), торговельнорозважальних центрів, інших закладів розважальної діяльності, спортивних залів, фітнес-центрів, торговельного і побутового обслуговування населення, крім:

торгівлі продуктами харчування, пальним, засобами гігієни, лікарськими засобами та виробами медичного призначення, ветеринарними препаратами, кормами, пестицидами та агрохімікатами, насінням і садивним матеріалом;

провадження банківської та страхової діяльності, а також медичної практики, ветеринарної практики, діяльності автозаправних комплексів, діяльності з технічного обслуговування та ремонту транспортних засобів, технічного обслуговування реєстраторів розрахункових операцій, діяльності 3 ремонту комп'ютерів, побутових виробів і предметів особистого вжитку, об'єктів поштового зв'язку;

торговельної діяльності та діяльності з надання послуг громадського харчування із застосуванням адресної доставки замовлень;

4) відвідування отримувачами соціальних або реабілітаційних послуг установ і закладів, що надають соціальні або реабілітаційні послуги сім'ям, особам, що перебувають у складних життєвих обставинах (тимчасове, денне перебування), крім установ і закладів, які надають соціальні послуги екстрено (кризово), центрів обліку бездомних осіб, мобільних бригад соціально-психологічної допомоги, соціального патрулювання.

Таким чином, згідно Постанови, на період карантину, в в містах Тернопілі, Бережанах, Чорткові та у Бережанському, Бучацькому, Гусятинському, Монастириському, Теребовлянському, Тернопільському та Чортківському районах заборонено відвідування закладів освіти здобувачами освіти. 
Відповідно до ст. 3 Конституції України, людина, її життя і здоров'я, честь і гідність, недоторканність і безпека визнаються в Україні найвищою соціальною цінністю. У ст. 53 Основного закону держави закріплено положення, що гарантує кожній особі право на освіту. Зокрема, повна загальна середня освіта є обов'язковою. Держава забезпечує доступність і безоплатність дошкільної, повної загальної середньої, професійно-технічної, вищої освіти в державних і комунальних навчальних закладах; розвиток дошкільної, повної загальної середньої, позашкільної, професійно-технічної, вищої і післядипломної освіти, різних форм навчання; надання державних стипендій та пільг учням і студентам.

Відповідно до ст. 64 Конституції України, конституційні права і свободи людини і громадянина не можуть бути обмежені, крім випадків, передбачених Конституцією України.

В умовах воєнного або надзвичайного стану можуть встановлюватися окремі обмеження прав і свобод із зазначенням строку дії цих обмежень. Не можуть бути обмежені права і свободи, передбачені

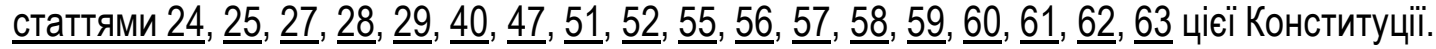

Станом на сьогоднішній день на території України не введено воєнного або надзвичайного стану, відтак, немає підстав для обмеження конституційних прав і свобод людини і громадянина.

Статтею 53 Конституції України та ст. 19 Закону України «Про охорону дитинства» встановлено, що повна загальна середня освіта $є$ обов'язковою. Держава забезпечує доступність і безоплатність дошкільної, повної загальної середньої, профресійно-технічної, вищої освіти в державних і комунальних навчальних закладах; розвиток дошкільної, повної загальної середньої, позашкільної, професійнотехнічної, вищої і післядипломної освіти, різних форм навчання; надання державних стипендій та пільг учням і студентам.

Виходячи із положень статей 7 та 8 Закону України «Про повну загальну середню освіту», не може бути обмежень у доступі до здобуття повної загальної середньої освіти. Територіальну доступність повної загальної середньої освіти забезпечують у межах повноважень органи державної влади та органи місцевого самоврядування шляхом:

- формування та утримання мережі закладів освіти, у тому числі опорних, їхніх структурних підрозділів (філій);

- функціонування міжшкільних ресурсних центрів;

- закріплення території обслуговування за комунальними закладами освіти (їхніми структурними підрозділами), що забезпечують здобуття початкової та/або базової середньої освіти;

- підвезення учнів та педагогічних працівників до закладу освіти і у зворотному напрямку, тощо.

Рішенням Конституційного Суду України від 04.03.2004 року № 5-рп/2004 визначено, що доступність освіти, як конституційна гарантія реалізації права на освіту на принципах рівності, визначених ст. 24 Конституції України (254-к/96-ВР), означає, що нікому не може бути відмовлено у праві на освіту, і держава має створити можливості для реалізації цього права. Такі ж положення визначено у ст. 2 Першого Протоколу до Конвенції про захист прав і основних свобод людини, у якій зазначено: нікому не може бути відмовлено у праві на освіту. Держава при виконанні будь-яких функцій, узятих нею на себе в галузі освіти і навчання, поважає право батьків забезпечувати таку освіту навчання відповідно до їхніх релігійних і світоглядних переконань.

У п.п. 3.2. Рішення Конституційного Суду України № 10-р/2020 року від 28 серпня 2020 року Конституційний Суд України наголошує, що обмеження конституційних прав і свобод людини і громадянина $є$ можливим у випадках, визначених Конституцією України. Таке обмеження може встановлюватися виключно законом - актом, ухваленим Верховною Радою України як єдиним органом законодавчої влади в Україні. Встановлення такого обмеження підзаконним актом суперечить статтям 1, 3, 6, 8, 19, 64 Конституції України.

Кабінет Міністрів України $є$ вищим виконавчим органом державної влади, який в силу статті 6 Конституції України може діяти лише у спосіб та в межах повноважень передбачених законом. У п. 4 рішення Конституційного суду України від 18 листопада 2004 року № 17-рп/2004 вказано, що здійснення державної влади на засадах її поділу на законодавчу, виконавчу та судову означає, передусім, самостійне виконання кожним органом державної влади своїх функцій і повноважень. Це не виключає взаємодії органів державної влади, в тому числі надання необхідної інформації, участь у 
підготовці або розгляді певного питання тощо. Однак така взаємодія має здійснюватися з урахуванням вимог статей 6, 19 Конституції України ( 254к/96-ВР ), відповідно до яких органи державної влади зобов'язані діяти на підставі, в межах повноважень та у спосіб, що передбачені Конституцією та законами України.

Статтею 64 Конституції України, на додаток до таких обмежень, що передбачені в конструкції окремих статей Конституції України щодо захисту прав людини, встановлює два виключні випадки, коли права людини можуть бути обмежені, - за умови надзвичайного чи воєнного стану.

Однак в Україні не було впроваджено надзвичайного стану. Натомість впроваджені Кабінетом Міністрів України обмеження називаються «карантинними» і вводяться в межах оголошення надзвичайної ситуації на території держави. Правовими підставами введення надзвичайної ситуації $€$ Закон України «Про забезпечення санітарного та епідемічного благополуччя населення» та Закон України «Про захист населення від інфекційних хвороб».

Але, ні Закон України «Про забезпечення санітарного та епідемічного благополуччя населення», ні Закон України «Про захист населення від інфекційних хвороб» не можуть наділяти Кабінет Міністрів України повноваженнями обмежувати конституційні права та свободи громадян в силу статті 64 Конституції України, яка встановлює можливість таких обмежень лише у випадку запровадження воєнного чи надзвичайного стану.

Водночас, ч. 3 статті 18 Конвенції про права дитини, яка ратифікована постановою Верховної Ради України № 789XII (79812) від 27 лютого 1991 року та набули чинності для України 27 вересня 1991 року визначено, що держави-учасниці вживають всіх необхідних заходів для забезпечення того, щоб діти, батьки яких працюють, мали право користуватися призначеними для них службами й установами по догляду за дітьми, а ст. 28 цієї Конвенції задекларовано, що держави-учасниці визнають право дитини на освіту, і з метою поступового досягнення здійснення цього права на підставі рівних можливостей вони, зокрема: а) вводять безплатну й обов'язкову початкову освіту; b) сприяють розвиткові різних форм середньої освіти, як загальної, так і професійної, забезпечують її доступність для всіх дітей та вживають таких заходів, як введення безплатної освіти та надання у випадку необхідності фінансової допомоги.

Згідно ч. 1 ст. 26 Загальної декларації прав людини, яка прийнята і проголошена резолюцією 217 А (III)Генеральної Асамблеї ООН від 10 грудня 1948 року, кожна людина має право на освіту. Освіта повинна бути безплатною, хоча б початкова і загальна. Початкова освіта повинна бути обов'язковою.

Стаття 13 Міжнародного пакту про економічні, соціальні і культурні права Держави, які беруть участь у цьому Пакті, визнають право кожної людини на освіту. Держави, які беруть участь у цьому Пакті, визнають, що для повного здійснення цього права: а) початкова освіта повинна бути обов'язкова і безплатна для всіх; b) середня освіта в її різних формах, включаючи професійно-технічну середню освіту, повинна бути відкрита і зроблена доступною для всіх шляхом вжиття всіх необхідних заходів і, зокрема, поступового запровадження безплатної освіти.

Виходячи з такого високого міжнародного рівня закріплення права дітей на освіту можна стверджувати, що воно є одним із основоположних прав, яке забезпечується регламентується всіма державами.

\section{IV Обговорення}

Відповідно до рішення штабу з ліквідації наслідків медико-біологічної надзвичайної ситуації природного характеру на території Тернопільської міської територіальної громади від 04.09.2020 року №36, вирішено Управлінню освіти і науки Тернопільської міської ради:

$\checkmark$ Забезпечити повноцінне (належне) функціонування закладів освіти за умов дотримання протиепідемічних вимог що рекомендовані МОЗ України.

$\checkmark$ Батькам (опікунам) очікувати дітей на вулиці поблизу закладів освіти.

$\checkmark$ Не допускати скупчення осіб, які очікують на дітей поблизу закладів освіти.

$\checkmark$ Забезпечити повноцінну роботу дошкільних та загальноосвітніх закладів.

$\checkmark$ В закладах дошкільної та загальної середньої освіти за участю медичних працівників визначати з числа вихованців, здобувачів освіти та персоналу осіб вікового та медичного ризику 
(імуносупресивні захворювання, цукровий діабет, хронічні захворювання та інші) застосувавши індивідуальний підхід.

Таким чином, керуючись рішенням штабу з ліквідації наслідків медико-біологічної надзвичайної ситуації природного характеру на території Тернопільської міської територіальної громади від 04.09.2020 року №36, навчальні заклади продовжували надавати освітні послуги після 07.09.2020 року.

Беручи до уваги постанову Кабінету Міністрів України від 22 липня 2020 р. за № 641 «Про встановлення карантину та запровадження посилених протиепідемічних заходів на території із значним поширенням гострої респіраторної хвороби COVID-19, спричиненої коронавірусом SARS-CoV-2», якою заборонено відвідування закладів освіти здобувачами освіти, проте, враховуючи загальнообов'язковий характер Конституції України, Закону України «Про освіту», право здобувачів освіти на їі здобуття та обов'язок щодо здобуття загальної середньої освіти, навчальні заклади продовжують роботу в звичайному режимі.

Єдиною альтернативою звичайного режиму відвідування загальноосвітніх навчальних закладів $€$ дистанційна форма навчання (відповідно до абз.3 ч.1 ст.9 ЗУ «Про освіту»).

Дистанційна фрорма здобуття освіти - це індивідуалізований процес здобуття освіти, який відбувається в основному за опосередкованої взаємодії віддалених один від одного учасників освітнього процесу у спеціалізованому середовищі, що функціонує на базі сучасних психологопедагогічних та інформаційно-комунікаційних технологій.

Відповідно до п.1.3. Положення про дистанційне навчання, затверджене Наказом Міністерства освіти і науки України 25.04.2013p. за № 466 (далі - Положення), це Положення поширюється на дистанційне навчання у:

- загальноосвітніх навчальних закладах (далі - ЗН3);

- професійно-технічних навчальних закладах (далі - ПТНЗ);

- вищих закладів освіти (далі - В3О);

- закладах післядипломної освіти або структурних підрозділах вищих навчальних закладів, наукових і освітньо-наукових установ, що здійснюють післядипломну освіту (далі - ЗПО).

Відповідно до п.2.1. Положення, дистанційне навчання реалізовується шляхом:

- застосування дистанційної форми як окремої форми навчання;

- використання технологій дистанційного навчання для забезпечення навчання в різних формах.

Згідно із п.2.2 Положення, запровадження дистанційної форми навчання у В3О, 3ПО можливе за погодженням з МОН України.

Дистанційна форма навчання у ЗНЗ, ПТНЗ запроваджується відповідно до рішення педагогічної ради, погодженого з органом управління освітою, у сфрері управління якого перебуває відповідний навчальний заклад (далі - орган управління освітою) (для навчальних закладів комунальної та державної форми власності), та за наявності кадрового і системотехнічного забезпечення, визначеного ЗНЗ згідно з розділом $\mathrm{V}$ цього Положення.

Станом на сьогоднішній день відсутні рішення педагогічних рад, погоджених з органами управління освітою, у сфері управління яких перебувають відповідні навчальні заклади (далі - органи управління освітою) (для навчальних закладів комунальної та державної форми власності), та відсутні кадрове і системотехнічне забезпечення, визначених ЗН3 згідно з розділом $\mathrm{V}$ цього Положення.

Відповідно до абз.3 п.2.4. Положення, дистанційне навчання організовується для учнів (вихованців), які:

- 3 будь-яких причин (стан здоров'я, проживання за межею пішохідної доступності до 3Н3, надзвичайні ситуації природного або техногенного характеру, воєнний конфлікт, проживання (перебування) за кордоном (для громадян України), на тимчасово окупованій території України або у населених пунктах, на території яких органи державної влади тимчасово не здійснюють або здійснюють не в повному обсязі свої повноваження, тощо) не можуть відвідувати навчальні заняття в 3Н3;

- за результатами останнього річного оцінювання навчальних досягнень опанували програмовий матеріал відповідного класу на високому рівні (10, 11, 12 балів).

Зарахування (переведення) на дистанційну форму навчання здійснюється за письмовою заявою повнолітньої особи та/або батьків (одного із батьків) або законного представника неповнолітньої особи. 
Приймання відповідних заяв учнів (вихованців) випускних класів 3Н3 закінчується до початку другого семестру навчання. Рішення щодо навчання учня (вихованця) за дистанційною формою приймається педагогічною радою та оформлюється наказом керівника 3 Н3.

Відповідно до п.4.1. Положення, у ЗН3 використання технологій дистанційного навчання зорієнтоване насамперед на такі категорії учнів (вихованців):

- особи з особливими потребами;

- обдаровані діти та молодь, які спроможні самостійно або прискорено опанувати навчальні програми;

- особи, які проживають у географічно віддалених і важкодоступних до 3Н3 населених пунктах;

- учні вечірніх шкіл, які за умовами праці перебувають тривалий час за межами населеного пункту, де розташований 3Н3, та учні, які за сімейними обставинами (декретна відпустка тощо) не можуть систематично відвідувати школу;

- особи, які бажають отримати додаткові знання паралельно з навчанням у школі;

- особи, які готуються до вступу до В3О;

- громадяни України, які тимчасово або постійно проживають за кордоном.

Згідно із п. 5.1. Положення, науково-методичне забезпечення дистанційного навчання включає:

- методичні (теоретичні та практичні) рекомендації щодо розроблення та використання педагогічно-психологічних та інформаційно-комунікаційних технологій дистанційного навчання;

- критерії, засоби і системи контролю якості дистанційного навчання;

- змістовне, дидактичне та методичне наповнення веб-ресурсів (дистанційних курсів) навчального плану/навчальної програми підготовки.

Як передбачено п. 5.2. Положення, педагогічні, науково-педагогічні працівники та методисти навчальних закладів, в яких організована дистанційна форма навчання, повинні підвищувати свою кваліфікацію щодо організації та володіння технологіями дистанційного навчання (не рідше одного разу на 5 років та обсягом не менше 108 академічних годин). Кваліфікація працівників, які підвищували свою кваліфікацію, має бути підтверджена документом про підвищення кваліфікації за тематикою дистанційного навчання.

Згідно із п.5.3. Положення, системотехнічне забезпечення дистанційного навчання включає:

- апаратні засоби (персональні комп'ютери, мережеве обладнання, джерела безперебійного живлення, сервери, обладнання для відеоконференц-зв'язку тощо), що забезпечують розроблення і використання веб-ресурсів навчального призначення, управління навчальним процесом та необхідні види навчальної взаємодії між суб'єктами дистанційного навчання у синхронному і асинхронному режимах;

- інфрормаційно-комунікаційне забезпечення із пропускною здатністю каналів, що надає всім суб'єктам дистанційного навчання навчального закладу цілодобовий доступ до веб-ресурсів і вебсервісів для реалізації навчального процесу у синхронному та асинхронному режимах;

- програмне забезпечення загального та спеціального призначення (у тому числі для осіб з особливими потребами), яке має бути ліцензійним або побудованим на програмних продуктах 3 відкритими кодами;

- веб-ресурси навчальних дисциплін (програм), що необхідні для забезпечення дистанційного навчання, можуть містити:

- методичні рекомендації щодо їх використання, послідовності виконання завдань, особливостей контролю тощо;

- документи планування навчального процесу (навчальні програми, навчально-тематичні плани, розклади занять);

- відео- та аудіозаписи лекцій, семінарів тощо;

- мультимедійні лекційні матеріали;

- термінологічні словники;

- практичні завдання із методичними рекомендаціями щодо їх виконання;

- віртуальні лабораторні роботи із методичними рекомендаціями щодо їх виконання;

- віртуальні тренажери із методичними рекомендаціями щодо їх використання; 
- пакети тестових завдань для проведення контрольних заходів, тестування із автоматизованою перевіркою результатів, тестування із перевіркою викладачем;

- ділові ігри із методичними рекомендаціями щодо їх використання;

- електронні бібліотеки чи посилання на них;

- бібліограсрії;

- дистанційний курс, що об'єднує зазначені вище веб-ресурси навчальної дисципліни (програми) єдиним педагогічним сценарієм;

- інші ресурси навчального призначення.

Перелік веб-ресурсів навчальних дисциплін (програм), необхідних для забезпечення дистанційного навчання, визначається закладом освіти залежно від профілю навчальної дисципліни.

Для забезпечення дистанційного навчання учнів, вихованців, студентів, слухачів навчальний заклад може створювати власні веб-ресурси або використовувати інші веб-ресурси, що підлягають перевірці у цьому навчальному закладі.

\section{V Висновки}

Станом на даний час у школах відсутня можливість, час, кошти для організації системотехнічного забезпечення дистанційного навчання, відтак, єдино можливою формою здійснення навчання $\epsilon$ відвідування шкіл у звичайному режимі. Поряд з цим, звертаємо увагу на те, що до початку навчального року органами управління освіти як обласних так і регіональних рівнів, органами місцевого самоврядування, на яких чинним законодавством покладено зобов'язання з питань реалізації розпоряджень органу виконавчої влади, що здійснює політику у сфері охорони здоров'я в контексті запобігання поширенню інфекційних хвороб та застосування протиепідемічних заходів, було проведено перевірку готовності закладів освіти до роботи у карантинних реаліях. Школи у достатніх обсягах забезпечені засобами індивідуального та колективного захисту. Це дає їм можливість здійснювати повноцінну діяльність та надавати освітні послуги здобувачам освіти.

\section{Бібліографрічні посилання}

1. Калинюк Н. М. До питання підготовки майбутніх медичних фахівців на засадах міждисциплінарної інтеграції / Інженерні та освітні технології. 2020. Т. 8. № 2. С. 44-52. doi: https://doi.org/10.30929/2307-9770.2020.08.02.04

2. Калинюк Н. М. Концептуальні засади інтеграції правової та професійно-практичної підготовки майбутніх фрахівців медичної галузі. Н. Калинюк, І. Рогальський / Медична освіта. № 3. 2020.

3. Калинюк Н. М. Щодо розуміння захворювання медичного працівника на COVID-19 як професійного: проблемні моменти // Київські правові читання «Приватне право в сфері охорони здоров'я: виклики і перспективи» (17 вересня 2020 р., м. Київ)

4. Мельничук І. М. Федірчик Т. Д., Калинюк Н. М. Сутність освіти як соціальної цінності. Вісник Національної академії Державної прикордонної служби України. Серія : Педагогіка. - 2019. - Bип. 1. URL: http://nbuv.gov.ua/UJRN/Vnadped_2019_1_7.1

5. Azaghouagh-El Fardi W. The Development of human capital of professional stall in a context of severe institutional pressure. Journal of Higher Education Policy and Management, Vollume 83, Issue 10 (2020) 73, 536 - 542 (2020). Doi: https://doi.org/10.1080/1360080X.2020.1836570

6. Armstrong M. A., Jovanovic J. The intersectional matrix: Rethinking institutional change for URM women in STEM. Journal of Diversity in Higher Education, 10(3), 2017. PP. 216-231.

7. Bach R. L., Perrucci C. C. Organizational influences on the sex composition of college and university faculty: A research note. Sociology of Education, 57(3), 1984. PP. 193-198.

8. Barba M., Krasniqi E., Ciliberto G. et al. Cancer patients and coronavirus disease 2019: evidence in context. J Transl Med, 18, 2020. 315. Doi: https://doi.org/10.1186/s12967-020-02483-w

9. Bauer G. R. Incorporating intersectionality theory into population health research methodology: Challenges and the potential to advance health equity. Social Science \& Medicine, 110(1), 2014. PP. 10-17. Doi: https://doi.org/10.1016/i.socscimed.2014.03.022

10. Blackwell J. E. Mentoring: An action strategy for increasing minority faculty. Academe, 75(5), 1989. PP. 8-14. Doi: https://doi.org/10.2307/40249734

11. Dollinger M., Lodge J. Student staff co-creation in higher education: an evidence-informed model to support future design and implementations. Journal of Higher Education Policy and Management, Vollume 42, Issue 5 (2020) 24. PP. $195-203$. https://doi.org/10.1080/1360080X.2019.1663681 
12. Dubé M., Kaba A., Cronin, T. et al. COVID-19 pandemic preparation: using simulation for systems-based learning to prepare the largest healthcare workforce and system in Canada. Adv Simul 5, 22 (2020). Doi: https://doi.org/10.1186/s41077-02000138-w

13. Jaguga F., Kwobah E. Mental health response to the COVID-19 pandemic in Kenya: a review. Int J Ment Health Syst 14, 68 (2020). Doi: https://doi.org/10.1186/s13033-020-00400-8

14. Kalyniuk N., Maika N., Rogalskyy I., Kadobnyi T., Lototska O. Certain aspects of training future medical specialists on the basis of interdisciplinary integration. International Journal of Management (IJM). September 2020: Vol. 11. Issue 9. P. 939-946. Doi: 10.34218/IJM.11.9.2020.086. URL: $\mathrm{t}$ http://www.iaeme.com/IJM/issues.asp?JType=IJM\&VType=11\&l Type=9

15. Marcus T.S., Heese J., Scheibe A. et al. Harm reduction in an emergency response to homelessness during South Africa's COVID-19 lockdown. Harm Reduct J 17, 60 (2020). Doi: https://doi.org/10.1186/s12954-020-00404-0

16. Meix-Cereceda P. Educational Values in Human Rights Treaties: UN, European, and African International Law. Hum Rights Rev 21, 437-461 (2020). https://doi.org/10.1007/s12142-020-00599-6

17. Villar J., Añón J.M., Ferrando, C. et al. Efficacy of dexamethasone treatment for patients with the acute respiratory distress syndrome caused by COVID-19: study protocol for a randomized controlled superiority trial. Trials 21, 717 (2020). Doi: https://doi.org/10.1186/s13063-020-04643-1

18. Wang Z., Fu S., Xu L. et al. Impact of Shenfu injection on a composite of organ dysfunction development in critically ill patients with coronavirus disease 2019 (COVID-19): A structured summary of a study protocol for a randomized controlled trial. Trials 21, 738 (2020). Doi: https://doi.org/10.1186/s13063-020-04677-5

19. Xu T., Ao M., Zhou X. et al. China's practice to prevent and control COVID-19 in the context of large population movement. Infect Dis Poverty 9, 115 (2020). Doi: https://doi.org/10.1186/s40249-020-00716-0

\section{References}

1. Kalyniuk, N. (2020). On the question of training of future medical specialists on the basis of interdisciplinary integration. Engineering and Educational Technologies, 8 (2), 44-52. doi: https://doi.org/10.30929/2307-9770.2020.08.02.04 [in Ukrainian]

2. Kalynyuk N. M. (2020). Kontseptual'ni zasady intehratsiyi pravovoyi ta profesiyno-praktychnoyi pidhotovky maybutnikh fakhivtsiv medychnoyi haluzi. N. Kalynyuk, O. Rohal's'kyy // Medychna osvita. № 3. 2020. [in Ukrainian]

3. Kalynyuk N. (2020). Shcho oznachaye rozuminnya dopomohy medychnoho pratsivnyka na COVID-19 yak profesiynoho: problemni momenty // Kyyivs'ki pravovi chytannya «Pryvatne pravo v haluzi okhorony zdorov'ya: vyklyky ta perspektyvy» (17 veresnya 2020, Kyiv). [in Ukrainian]

4. Mel'nychuk I.M. (2019) Fedirchyk T.D., Kalynyuk N.M. Sutnist' osvity yak sotsial'noyi tsinnosti. Visnyk Natsional'noyi akademiyi Derzhavnoyi prykordonnoyi sluzhby Ukrayiny. Seriya : Pedahohika. - 2019. - Vyp. 1. - Rezhym dostupu: http://nbuv.gov.ua/UJRN/Vnadped_2019_1_7.1 [in Ukrainian]

5. Azaghouagh-El Fardi W. The Development of human capital of professional stall in a context of severe institutional pressure. Journal of Higher Education Policy and Management, Vollume 83, Issue 10 (2020) 73, 536 - 542 (2020). https://doi.org/10.1080/1360080X.2020.1836570

6. Armstrong, M. A., \& Jovanovic, J. (2017). The intersectional matrix: Rethinking institutional change for URM women in STEM. Journal of Diversity in Higher Education, 10(3), 216- 231.

7. Bach, R. L., \& Perrucci, C. C. (1984). Organizational influences on the sex composition of college and university faculty: A research note. Sociology of Education, 57(3), 193- 198.

8. Barba, M., Krasniqi, E., Ciliberto, G. et al. Cancer patients and coronavirus disease 2019: evidence in context. J Transl Med 18, 315 (2020). https://doi.org/10.1186/s12967-020-02483-w

9. Bauer, G. R. (2014). Incorporating intersectionality theory into population health research methodology: Challenges and the potential to advance health equity. Social Science \& Medicine, 110(1), 10- 17. https://doi.org/10.1016/i.socscimed.2014.03.022

10. Blackwell, J. E. (1989). Mentoring: An action strategy for increasing minority faculty. Academe, 75(5), 814. https://doi.org/10.2307/40249734

11. Dollinger M., Lodge J. Student staff co-creation in higher education: an evidence-informed model to support future design and implementations. Journal of Higher Education Policy and Management, Vollume 42, Issue 5 (2020) 24, 195 - 203 (2020). https://doi.org/10.1080/1360080X.2019.1663681

12. Dubé, M., Kaba, A., Cronin, T. et al. COVID-19 pandemic preparation: using simulation for systems-based learning to prepare the largest healthcare workforce and system in Canada. Adv Simul 5, 22 (2020). https://doi.org/10.1186/s41077-020-00138-w

13. Jaguga, F., Kwobah, E. Mental health response to the COVID-19 pandemic in Kenya: a review. Int J Ment Health Syst 14, 68 (2020). https://doi.org/10.1186/s13033-020-00400-8

14. Kalyniuk N., Maika N., Rogalskyy I., Kadobnyi T., Lototska O. Certain aspects of training future medical specialists on the basis of interdisciplinary integration. International Journal of Management (IJM). September 2020: Vol. 11. Issue 9. P. 939-946. DOI: 10.34218/IJM.11.9.2020.086 URL: $\mathrm{t}$ http://www.iaeme.com/lJM/issues.asp?JType=|JM\&VType=11\&IType=9

15. Marcus, T.S., Heese, J., Scheibe, A. et al. Harm reduction in an emergency response to homelessness during South Africa's COVID-19 lockdown. Harm Reduct J 17, 60 (2020). https://doi.org/10.1186/s12954-020-00404-0

16. Meix-Cereceda, P. Educational Values in Human Rights Treaties: UN, European, and African International Law. Hum Rights Rev 21, 437-461 (2020). https://doi.org/10.1007/s12142-020-00599-6

17. Villar, J., Añón, J.M., Ferrando, C. et al. Efficacy of dexamethasone treatment for patients with the acute respiratory distress syndrome caused by COVID-19: study protocol for a randomized controlled superiority trial. Trials 21, 717 (2020). https://doi.org/10.1186/s13063-020-04643-1 
18. Wang, Z., Fu, S., Xu, L. et al. Impact of Shenfu injection on a composite of organ dysfunction development in critically ill patients with coronavirus disease 2019 (COVID-19): A structured summary of a study protocol for a randomized controlled trial. Trials 21, 738 (2020). https://doi.org/10.1186/s13063-020-04677-5

19. Xu, T., Ao, M., Zhou, X. et al. China's practice to prevent and control COVID-19 in the context of large population movement. Infect Dis Poverty 9, 115 (2020). https://doi.org/10.1186/s40249-020-00716-0

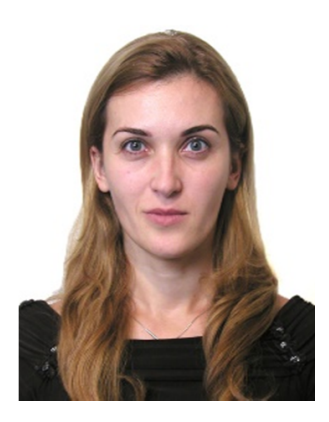

Калинюк Наталя Миколаївна.

Кандидат юридичних наук, доцент, доцент кафедри педагогіки вищої школи та суспільних дисциплін Тернопільського національного медичного університету імені І.Я. Горбачевського,

Майдан Волі, 1, м. Тернопіль, Україна, 46001

Тел. +380976539021 .E-mail: kalunyknm@tdmu.edu.ua

\section{Kalyniuk Natalia Mykolayvna.}

PhD. JuD, Associate Professor, Associate Professor of the Department of Pedagogy of the Higher School and Social Science,

I. Horbachevsky Ternopil National Medical University,

sit. M. Voli, 1, Ternopil, Ukraine.

Tel. +380976539021 . E-mail: kalunyknm@tdmu.edu.ua

ORCID: 0000-0002-1613-835X

\section{Citation (APA):}

Kalyniuk N. M. (2020). Realization of the human right to education in quarantine conditions: Ukrainian realities. Engineering and Educational Technologies, 8 (4), 8-18. doi: https://doi.org/10.30929/2307-9770.2020.08.04.01

\section{Цитування (ДСТУ 8302:2015):}

Калинюк Н. М. Реалізація особою права на освіту в умовах карантину: українські реалії / Інженерні та освітні технології. 2020.

T. 8. № 4. C. 8-18. doi: https://doi.org/10.30929/2307-9770.2020.08.04.01

Обсяг статmі: сторінок-11; умовних друк. аркушів - 1,593. 